\title{
Significance of silica in identifying the processes affecting groundwater chemistry in parts of Kali watershed, Central Ganga Plain, India
}

\author{
Arina Khan · Rashid Umar • Haris Hasan Khan
}

Received: 27 June 2013 / Accepted: 20 February 2014/Published online: 17 March 2014

(C) The Author(s) 2014. This article is published with open access at Springerlink.com

\begin{abstract}
Chemical geothermometry using silica was employed in the present study to estimate the sub-surface groundwater temperature and the corresponding depth of the groundwater in parts of Kali watershed in Bulandshahr and Aligarh district. 42 groundwater samples each were collected from borewells during pre-monsoon and postmonsoon season 2012 and analysed for all major ions and silica. Silica values in the area range from 18.72 to $50.64 \mathrm{mg} / \mathrm{l}$ in May 2012 and from 18.89 to $52.23 \mathrm{mg} / \mathrm{l}$ in November 2012. Chalcedony temperature $>60{ }^{\circ} \mathrm{C}$ was deduced for five different locations in each season, which corresponds to a depth of more than 1,000 metres. Spatial variation of silica shows high values along a considerable stretch of River Kali, during pre-monsoon season. Relationship of silica with Total Dissolved Solids and Chloride was established to infer the role of geogenic and anthropogenic processes in solute acquisition. It was found that both water-rock interaction and anthropogenic influences are responsible for the observed water chemistry.
\end{abstract}

Keywords Groundwater - Chemistry · Silica geothermometry $\cdot$ Chalcedony $\cdot$ River Kali

\footnotetext{
A. Khan $(\bowtie) \cdot$ R. Umar

Department of Geology, Aligarh Muslim University,

Aligarh, India

e-mail: arinakhan10@gmail.com

H. H. Khan

Department of Earth Sciences, Pondicherry University,

Pondicherry, India
}

\section{Introduction}

Groundwater temperature is a direct indicator of geothermal influence. Chemical geothermometry is a technique that can be used to estimate sub-surface reservoir temperatures using concentration of certain elements in groundwater. Geothermometers provide important information on the reservoir temperatures. They are based on temperaturedependent mineral equilibria. The information obtained from geothermometers is inexpensive and reliable. The quartz and $\mathrm{Na}-\mathrm{K}$ geothermometers are the most commonly used chemical geothermometers (Hailemichael 2008). Unfortunately, the predicted temperatures generally show a wide dispersion even when applying a single geothermometer to all the wells in an area. Many reasons have been proposed to justify the discrepancies, including gain or loss of steam phase in the reservoir, mixing of different types of fluids, re-equilibration during ascension to superficies, precipitation-dissolution, etc. (Truesdell and Fournier 1977; Verma 2000).

The application of chemical geothermometers is based on a number of assumptions (Fridriksson and Armannsson 2007). When geothermometers are applied to estimate subsurface or aquifer temperatures, a basic assumption is that temperature-dependent chemical or isotopic equilibria prevail in the source aquifer. It is assumed that the chemical and isotopic reactions do not significantly modify the composition of fluid as it ascends from the source aquifer to the sampling point (Karingthi 2009).

Silica in groundwater is exclusively derived from waterrock interaction. The circulating groundwater dissolves the silica derived from the chemical weathering of silicate minerals in rocks and sediments (Hem 1959). $\mathrm{SiO}_{2}$ concentration in groundwater ranges from 1 to $30 \mathrm{mg} / \mathrm{l}$, usually around $17 \mathrm{mg} / \mathrm{l}$. Silica content in groundwater is 
directly proportional to its residence time (Marchand et al. 2002), since prolonged contact with silicate rocks increases the $\mathrm{Si}$ concentration. Hence, water ascending from deeper reservoir is rich in silica as compared to shallow groundwater. Factors like permeability, lithology and residence time of groundwater control the intensity of water-rock interaction which in turn dictates the silica content in groundwater. Study by McMahon et al. (1995) has shown that organic acid-rich groundwater enhanced quartz/kfeldspar dissolution in the aquifer. However, temperature has a direct control over the silica solubility in groundwater (Fournier 1983). Due to the consistency of the temperaturesilica solubility relationship, it is used as a geothermometer in groundwater and geothermal studies.

Silica concentration in groundwater has been correlated with different parameters such as regional heat flow values (Swanberg and Morgan 1978; Geological survey of India 1991), temperature condition at the time of silica acquisition (Fournier 1983; Boughton and McCoy 2006), waterrock interaction (Marchand et al. 2002; Fournier 1983), total dissolved solids (TDS) and specific electrical conductivity (Barbara and Harry 1984) and TDS and Chloride $\left(\mathrm{Cl}^{-}\right)$(Khan and Umar 2010). Silica geothermometry was applied on thermal groundwaters in the Gulf of Suez region, Egypt (El-Fiky 2009) and the results showed that the sub-surface temperatures range between 29.4 and $104.5^{\circ} \mathrm{C}$. Ferguson et al. (2009) studied the potential for mixing and re-equilibration of water by examining heat and fluid flow along crustal scale faults along tectonic geothermal systems and found that significant mixing with shallow groundwater will occur resulting in an under-prediction of maximum circulation temperature by $10-35 \%$ using silica and chalcedony geothermometers. Silica was correlated with TDS and $\mathrm{Cl}^{-}$(Khan and Umar 2010) to study the effect of various geogenic and anthropogenic processes on groundwater chemistry.

In the present study, silica-based geothermometer of Fournier (1983) has been used because the formulation provides a simple and unique relationship between temperature and silica concentration. It was employed to estimate the sub-surface groundwater temperature and the corresponding depth of groundwater. Further, silica values were correlated with TDS and $\mathrm{Cl}^{-}$values, using the conventional graphical methods, to understand the role of anthropogenic activities and geogenic processes on groundwater chemistry.

\section{Study area}

The study area, covering about $665 \mathrm{~km}^{2}$, is a part of Kali watershed in Bulandshahr and Aligarh district. Geographic coordinates of the area are $28^{\circ} \mathrm{N}$ to $28^{\circ} 15^{\prime} \mathrm{N}$ and $77^{\circ} \mathrm{E}$ to $77^{\circ} 15^{\prime} \mathrm{E}$. Kali is the major river flowing through the area, which experiences a tropical monsoon type of climate. The study area is flat plain with a general slope from north-west to south-east. The area is underlain by a moderately thick pile of Quaternary sediments, which comprise sands of various grades, clays and kankar. Alluvial sediments overlie Vindhyan group of rocks of Proterozoic age in an unconformable way, and thickness of alluvial deposits varies from 287 to $380 \mathrm{~m}$ (CGWB 2002). The entire area has a top clay layer ranging in thickness from 3 to $8 \mathrm{~m}$ below ground level. Sandy horizon forms the potential aquifer. Groundwater occurs under water table conditions and depth to water varies between 2.23 and $12.4 \mathrm{~m} \mathrm{bgl}$. The general groundwater flow direction is from NW to SE.

\section{Methodology}

Groundwater samples were collected from 42 borewells in the study area during May and November 2012 for silica and major ion analysis (Fig. 1). The sampling wells were carefully selected to spread the sampling points over the study area evenly. The geographical coordinates of the borewells were captured using a handheld Garmin e-Trex GPS receiver. Silica analysis was carried out using ammonium molybdate spectrophotometric method. Major ions were analysed as per the standard methods of APHA (1992).

\section{Silica geothermometry}

Swanberg and Morgan (1978) applied silica geothermometer to over 70,000 non-thermal groundwater samples of USA and unequivocally showed that there is a strong correlation between silica geotemperatures for a given region and the known regional heat flow. They arrived at a relationship

\section{Silica derived temperature in groundwater $\left(\operatorname{Tin}^{\circ} \mathrm{C}\right)$ $=m q+b$}

where $\mathrm{q}$ is the regional heat flow in $\mathrm{mWm}^{-2}$ and $\mathrm{m}$ and $\mathrm{b}$ are constants with values $0.67{ }^{\circ} \mathrm{C} \mathrm{m}^{2} \mathrm{~mW}^{-1}$ and $13.2{ }^{\circ} \mathrm{C}$, respectively. Constant $b$ is related to the mean air temperature and $\mathrm{m}$ is related to the depth to which water descends. They further demonstrated that the estimated depth of the occurrence of the groundwater in deep steady state is $1,400-2,000 \mathrm{~m}$.

The first silica geothermometer equation was presented by Morey et al. (1962). Various silica geothermometer equations have been developed over the years to assess sub-surface temperatures from the silica content of natural water in equilibrium with either quartz or chalcedony. 


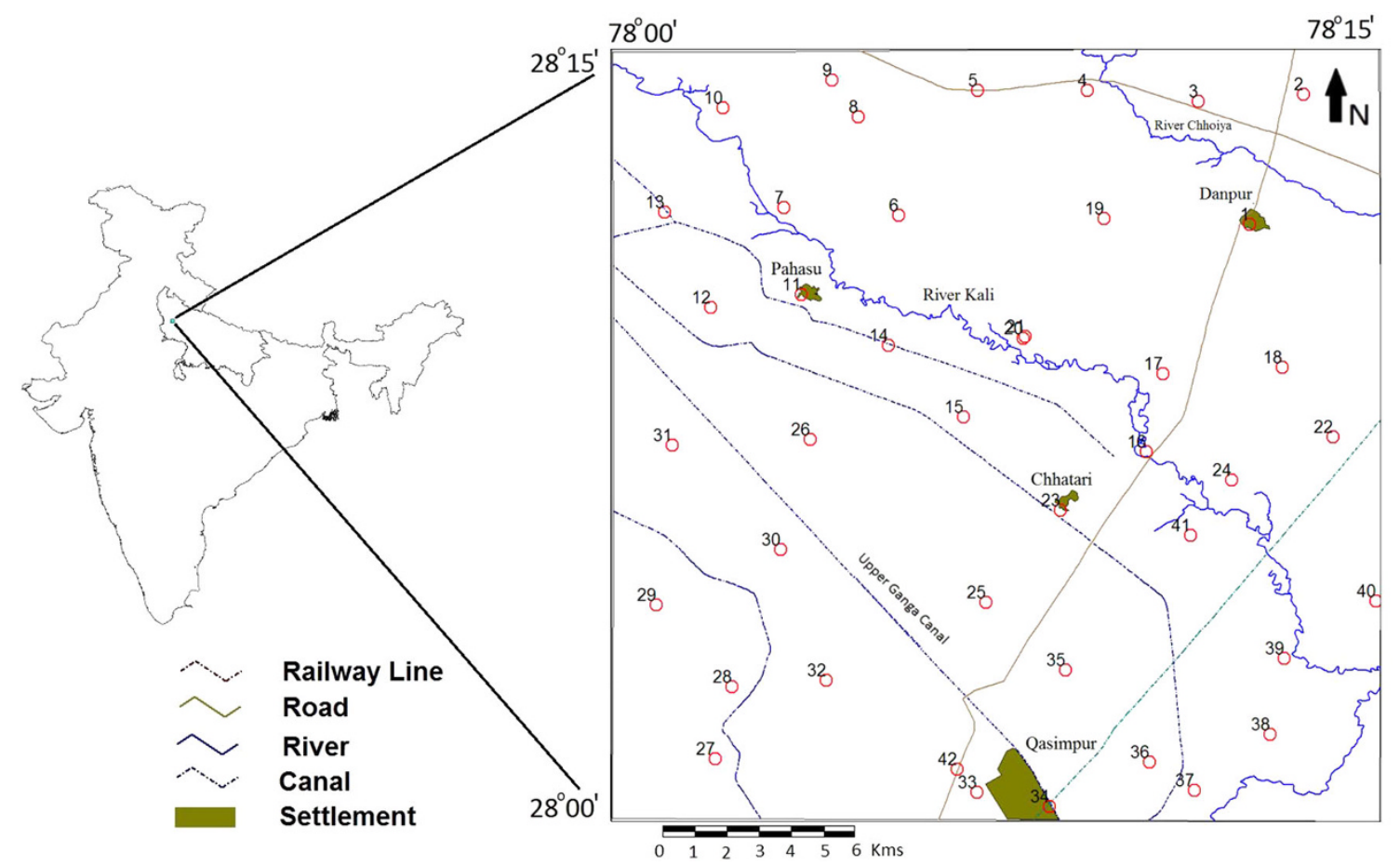

Fig. 1 Map of the study area showing sampling locations

Temperatures estimated by these geothermometers are referred to as quartz and chalcedony temperatures, respectively (Arnorsson 2000). The quartz geothermometer is generally applied in high-temperature systems while the chalcedony geothermometer is used in low-temperature systems. The one which seems to be appropriate for groundwater systems is given by Fournier (1983). The following equation takes into account the solubility of chalcedony:

$t^{\circ} \mathrm{C}=\left[(1032) /\left(4.69-\log \mathrm{SiO}_{2}\right)\right]-273.15$

where, $\mathrm{SiO}_{2}$ concentration of water sample is in $\mathrm{mg} / \mathrm{l}$ and $t^{\circ} \mathrm{C}$ is the chalcedony-derived temperature of groundwater.

Substituting the determined silica values in the above equation, we can calculate the chalcedony temperature of the groundwater. Thus, a groundwater sample with higher silica content would represent more water-rock interaction at a relatively high temperature level than a sample with lower silica content. Converting silica values to aquifer temperature provides an estimate to the depth of aquifer assuming normal geothermal gradient of $30{ }^{\circ} \mathrm{C} / \mathrm{km}$. The main purpose of this approach is to make a distinction between water of deeper origin and shallower origin, which can provide a significant clue either to geogenic or anthropogenic involvement in evolving groundwater quality.

\section{Results and discussion}

Results of silica analysis and temperatures deduced using the chalcedony thermometry for both the time periods (May 2012 and November 2012) are given in Table 1. In addition to silica and the temperatures estimated, the table also gives other parameters such as $\mathrm{Cl}$ and TDS with which silica has been correlated. All the parameters, including silica, are given in $\mathrm{mg} / \mathrm{l}$.

The silica values in the region vary from about 18.72 to $50.64 \mathrm{mg} / \mathrm{l}$ in May 2012 with an average value of around $27 \mathrm{mg} / \mathrm{l}$ and from 18.89 to $52.23 \mathrm{mg} / \mathrm{l}$ in November 2012 with an average of $29 \mathrm{mg} / \mathrm{l}$. Five samples in May 2012 and 4 samples in November 2012 show silica values $>40 \mathrm{mg} / \mathrm{l}$. In May 2012, maximum chalcedony temperatures of more than $60{ }^{\circ} \mathrm{C}$ were determined at Jagdishpur, Bahlolpur, Pindrawal, Bigupur and Kazimabad. The temperatures deciphered for the remaining samples range from 28 to $58{ }^{\circ} \mathrm{C}$.

In Nov 2012, the chalcedony temperature of the sample at Pindrawal still shows a high value of about $60{ }^{\circ} \mathrm{C}$, while the samples of Kazimabad, Bigupur and Jagdishpur show a decline in silica values which correspond to a temperature of about $41.5,42$ and $36{ }^{\circ} \mathrm{C}$, respectively, and this decline can be attributed to the dilution of silica concentration in post-monsoon period. The silica concentration of samples 
Table 1 Silica, Chloride, TDS concentration in mg/l (May and Nov 2012)

\begin{tabular}{|c|c|c|c|c|c|c|c|c|c|}
\hline \multicolumn{6}{|c|}{ May 2012} & \multicolumn{4}{|c|}{ November 2012} \\
\hline S.No. & Location & $\mathrm{SiO}_{2}(\mathrm{mg} / \mathrm{l})$ & $\mathrm{Cl}$ & TDS & Chalcedony $\left({ }^{\circ} \mathrm{C}\right)$ & $\mathrm{SiO}_{2}(\mathrm{mg} / \mathrm{l})$ & $\mathrm{Cl}$ & TDS & Chalcedony $\left({ }^{\circ} \mathrm{C}\right)$ \\
\hline 1 & Danpur & 25.00 & 173.24 & 1,340 & 40.33 & 37.68 & 42.6 & 456 & 58.27 \\
\hline 2 & Kheriya Bakhsh & 23.21 & 22.72 & 437 & 37.28 & 26.06 & 14.2 & 562 & 42.06 \\
\hline 3 & Daulatpur Khurd & 20.13 & 96.56 & 653 & 31.62 & 28.71 & 99.4 & 750 & 46.16 \\
\hline 4 & Maurajpur & 32.31 & 17.04 & 477 & 51.31 & 22.46 & 25.56 & 484 & 35.96 \\
\hline 5 & Ahmadgarh & 21.92 & 124.96 & 1,037 & 34.99 & 24.67 & 144.84 & 973 & 39.78 \\
\hline 6 & Bhaiyanpur & 20.38 & 11.36 & 347 & 32.11 & 19.18 & 85.2 & 732 & 29.74 \\
\hline 7 & Surjaoli & 19.49 & 56.80 & 736 & 30.36 & 34.23 & 73.84 & 855 & 53.89 \\
\hline 8 & Lalner & 23.33 & 8.52 & 298 & 37.50 & 36.49 & 76.68 & 536 & 56.79 \\
\hline 9 & Jagdishpur & 40.13 & 159.04 & 1,162 & 61.20 & 22.38 & 59.64 & 452 & 35.82 \\
\hline 10 & Utrawali & 33.21 & 59.64 & 706 & 52.53 & 19.9 & 79.52 & 682 & 31.17 \\
\hline 11 & Pahasu & 21.54 & 22.72 & 414 & 34.29 & 20.48 & 73.84 & 822 & 32.30 \\
\hline 12 & Banail & 21.03 & 99.40 & 856 & 33.33 & 27.03 & 19.88 & 465 & 43.59 \\
\hline 13 & Aterna & 19.49 & 11.36 & 277 & 30.36 & 38.81 & 11.36 & 211 & 59.64 \\
\hline 14 & Bedrampur & 23.08 & 18.52 & 564 & 37.06 & 22.47 & 22.72 & 570 & 35.98 \\
\hline 15 & Kamauna & 21.67 & 19.88 & 418 & 34.52 & 41.55 & 31.24 & 504 & 62.85 \\
\hline 16 & H. Pump near Kali & 24.23 & 31.24 & 678 & 39.04 & 37.82 & 25.56 & 430 & 58.44 \\
\hline 17 & Chaundhera & 25.38 & 34.08 & 806 & 40.96 & 22.34 & 42.6 & 751 & 35.75 \\
\hline 18 & Akbarpur & 35.13 & 159.04 & 1,138 & 55.06 & 21.67 & 122.12 & 862 & 34.53 \\
\hline 19 & Salabad & 25.77 & 38.40 & 543 & 41.59 & 18.89 & 79.52 & 461 & 29.16 \\
\hline 20 & Bigupur t. well & 37.31 & 59.64 & 648 & 57.81 & 34.97 & 28.4 & 658 & 54.85 \\
\hline 21 & Bigupur h. pump & 49.36 & 42.60 & 695 & 71.24 & 26.08 & 51.12 & 708 & 42.09 \\
\hline 22 & Darora & 24.62 & 17.04 & 260 & 39.69 & 33.89 & 17.04 & 251 & 53.44 \\
\hline 23 & Chhatari & 20.26 & 11.36 & 337 & 31.87 & 41.27 & 11.36 & 312 & 62.53 \\
\hline 24 & Pindrawal & 45.00 & 22.72 & 510 & 66.68 & 39.89 & 19.88 & 500 & 60.92 \\
\hline 25 & Bahlolpur & 42.69 & 8.52 & 317 & 64.14 & 21.19 & 25.56 & 577 & 33.64 \\
\hline 26 & Teori & 25.38 & 56.80 & 679 & 40.96 & 37 & 14.2 & 325 & 57.43 \\
\hline 27 & Daudpur Kota & 32.44 & 11.36 & 378 & 51.48 & 30.48 & 14.2 & 370 & 48.75 \\
\hline 28 & Sikanderpur Kota & 22.05 & 17.04 & 457 & 35.23 & 24.17 & 25.56 & 484 & 38.94 \\
\hline 29 & Tamkoli & 23.85 & 14.20 & 409 & 38.39 & 21.75 & 14.2 & 375 & 34.68 \\
\hline 30 & Barauli & 20.38 & 8.52 & 585 & 32.11 & 26.22 & 42.6 & 628 & 42.31 \\
\hline 31 & Paharpur & 25.90 & 45.44 & 572 & 41.80 & 34.09 & 156.2 & 1,073 & 53.70 \\
\hline 32 & Sonana & 20.38 & 71.00 & 818 & 32.11 & 21.49 & 17.04 & 378 & 34.20 \\
\hline 33 & Nagola & 23.46 & 5.68 & 492 & 37.73 & 27.03 & 11.36 & 370 & 43.59 \\
\hline 34 & Qasimpur & 23.21 & 8.52 & 188.6 & 37.28 & 34.46 & 11.36 & 164.4 & 54.19 \\
\hline 35 & Pilona & 35.77 & 11.36 & 414 & 55.88 & 52.23 & 14.2 & 489 & 74.08 \\
\hline 36 & Gopalpur & 18.97 & 14.20 & 373 & 29.33 & 37.17 & 14.2 & 376 & 57.64 \\
\hline 37 & Kheda Buzurg & 31.28 & 14.20 & 420 & 49.88 & 26.21 & 14.2 & 356 & 42.30 \\
\hline 38 & Chhalesar & 18.72 & 22.72 & 399 & 28.80 & 20.38 & 25.56 & 308 & 32.10 \\
\hline 39 & Sikharna & 24.87 & 45.44 & 527 & 40.12 & 44.92 & 48.28 & 497 & 66.60 \\
\hline 40 & Kazimabad & 50.64 & 107.92 & 789 & 72.52 & 25.76 & 110.76 & 743 & 41.57 \\
\hline 41 & Chauganpur & 23.33 & 36.92 & 497 & 37.50 & 19.66 & 53.96 & 608 & 30.70 \\
\hline 42 & Near Ash Pond & 24.23 & 38.52 & 603 & 39.04 & 30.1 & 14.2 & 567 & 48.20 \\
\hline
\end{tabular}

in Nov 2012 varies from 18.89 to $52.23 \mathrm{mg} / \mathrm{l}$ and the chalcedony temperature varies from approximately 29 to $74{ }^{\circ} \mathrm{C}$ with 5 values having $>60{ }^{\circ} \mathrm{C}$ temperature.
In May 2012, when the ambient air temperature was in excess of $30{ }^{\circ} \mathrm{C}$, a silica temperature of $66^{\circ} \mathrm{C}$ would mean a temperature of about $35^{\circ} \mathrm{C}$ over and above the average 
Fig. 2 a Spatial distribution map of silica (May 2012). b Spatial distribution map of silica (November 2012)
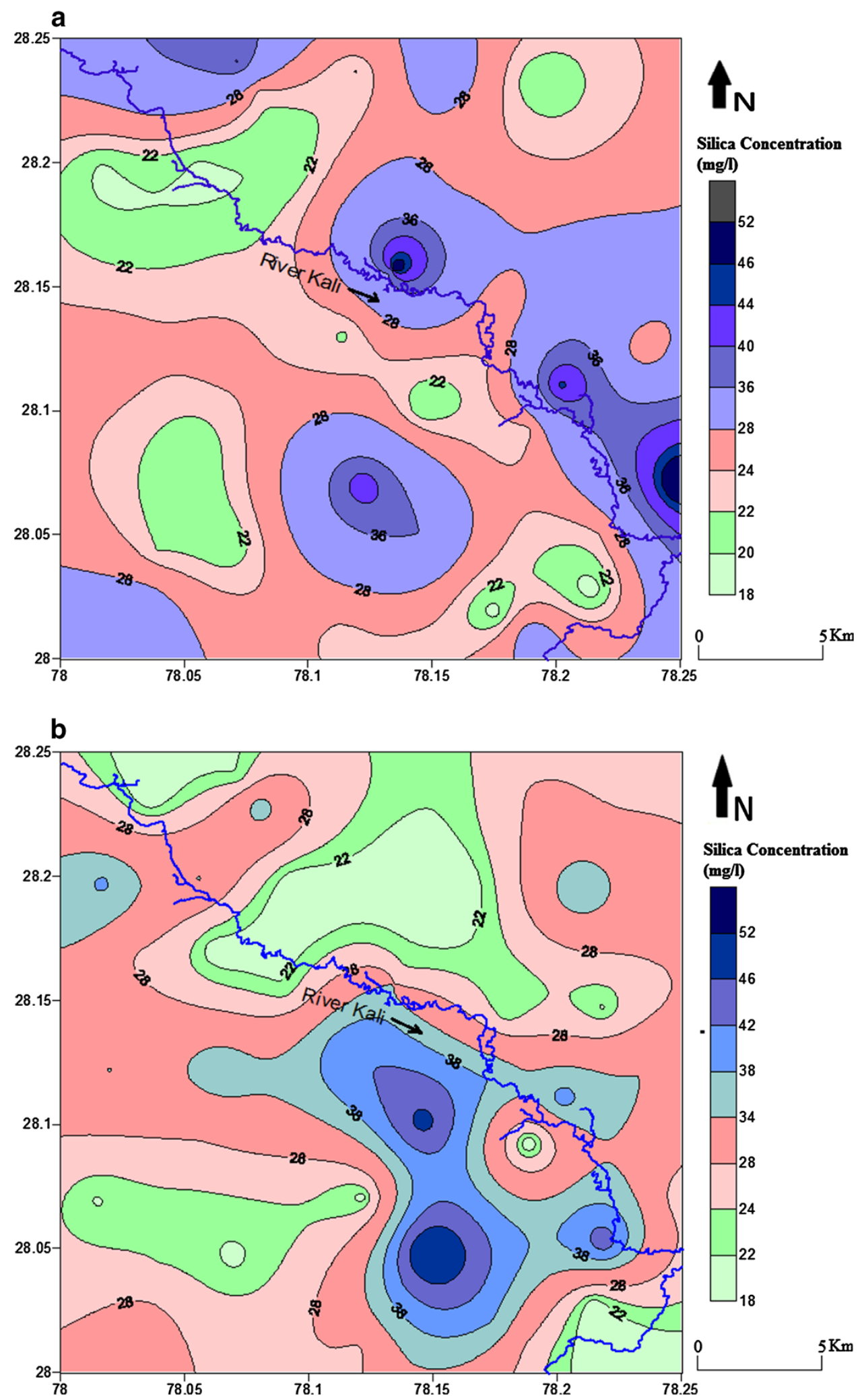

air temperature, which in turn would correspond to a depth of about 1,000 m taking into account an average geothermal gradient of $30{ }^{\circ} \mathrm{C} / \mathrm{km}$ (GSI 1991). In this way, samples that have silica values $>40 \mathrm{mg} / \mathrm{l}$ and temperature more than $60{ }^{\circ} \mathrm{C}$ correspond to a depth of about $1,000 \mathrm{~m}$ or more.

The spatial variation in the silica values in groundwater of the study area is shown in Fig. 2a and b, representing 
pre-monsoon and post-monsoon distributions, respectively. In Fig. 2a, high values of silica ( $>36 \mathrm{mg} / \mathrm{l})$ are observed in the eastern and the central part (Bigupur, Kazimabad and Pindrawal) and two isolated silica highs are also observed, one in the northern part (Jagdishpur) and the other (Bahlolpur) in the southern part. In most of the region, the values range from 22 to $28 \mathrm{mg} / \mathrm{l}$. Except a few locations, it is generally observed that silica values are higher along river Kali. This suggests that river Kali is receiving groundwater discharge from local groundwater system and possibly from deeper and regional groundwater system, too.

In post-monsoon period, isolated silica highs are observed in some areas in the north with values 36.49 , 38.81 and $37.68 \mathrm{mg} / 1$ in Lalner, Aterna and Danpur, respectively. Most of the region shows an average value of $28 \mathrm{mg} / \mathrm{l}$. However, these silica highs do not coincide with the Kali River. This may be due to the enhanced circulation of groundwater in the shallow local groundwater system. Silica concentration is dependent on the relative proportion of local (shallow) and regional (deep) groundwater flux. Since local system has a rapid response to seasonal fluctuation, shallow groundwater influx will decrease in premonsoon and increase in post-monsoon. This will lead to the dilution of deeper, silica-rich, regional groundwater flow during post-monsoon.

\section{Relationship of silica with chloride}

Chloride acts as an inert element in practically all natural water-rock environments, i.e. once in solution, it stays there both at ambient and elevated temperatures (Ellis 1970). It usually does not enter common rock-forming minerals due to the large size of its ion and hence does not participate in ion exchange in groundwater. Presence of high amounts of $\mathrm{Cl}$ in groundwater undoubtedly indicates anthropogenic influence on the groundwater chemistry, whereas silica enters the groundwater system exclusively and unequivocally through rock-water interaction (Hem 1959). Keeping this in consideration, $\mathrm{Cl}$ values have been related to silica concentrations for both the time periods (Fig. 3a, b) to evaluate the role of anthropogenic and natural activities in ion acquisition.

$\mathrm{SiO}_{2}$ versus $\mathrm{Cl}$ plot of May 2012 (Fig. 3a) shows that for almost similar $\mathrm{SiO}_{2}$ values of $19-25 \mathrm{mg} / \mathrm{l}, \mathrm{Cl}$ increases to as high as $173 \mathrm{mg} / \mathrm{l}$. This indicates that bulk of $\mathrm{Cl}^{-}$has been acquired by processes other than geogenic. Samples 9, 18 and 40 show high $\mathrm{SiO}_{2}$ as well as high $\mathrm{Cl}$ values suggesting that both rock-water interaction and anthropogenic factors influence the chemistry of these samples.

$\mathrm{SiO}_{2}$ vs. $\mathrm{Cl}$ plot of Nov 2012 (Fig. 3b) shows three distinct features:
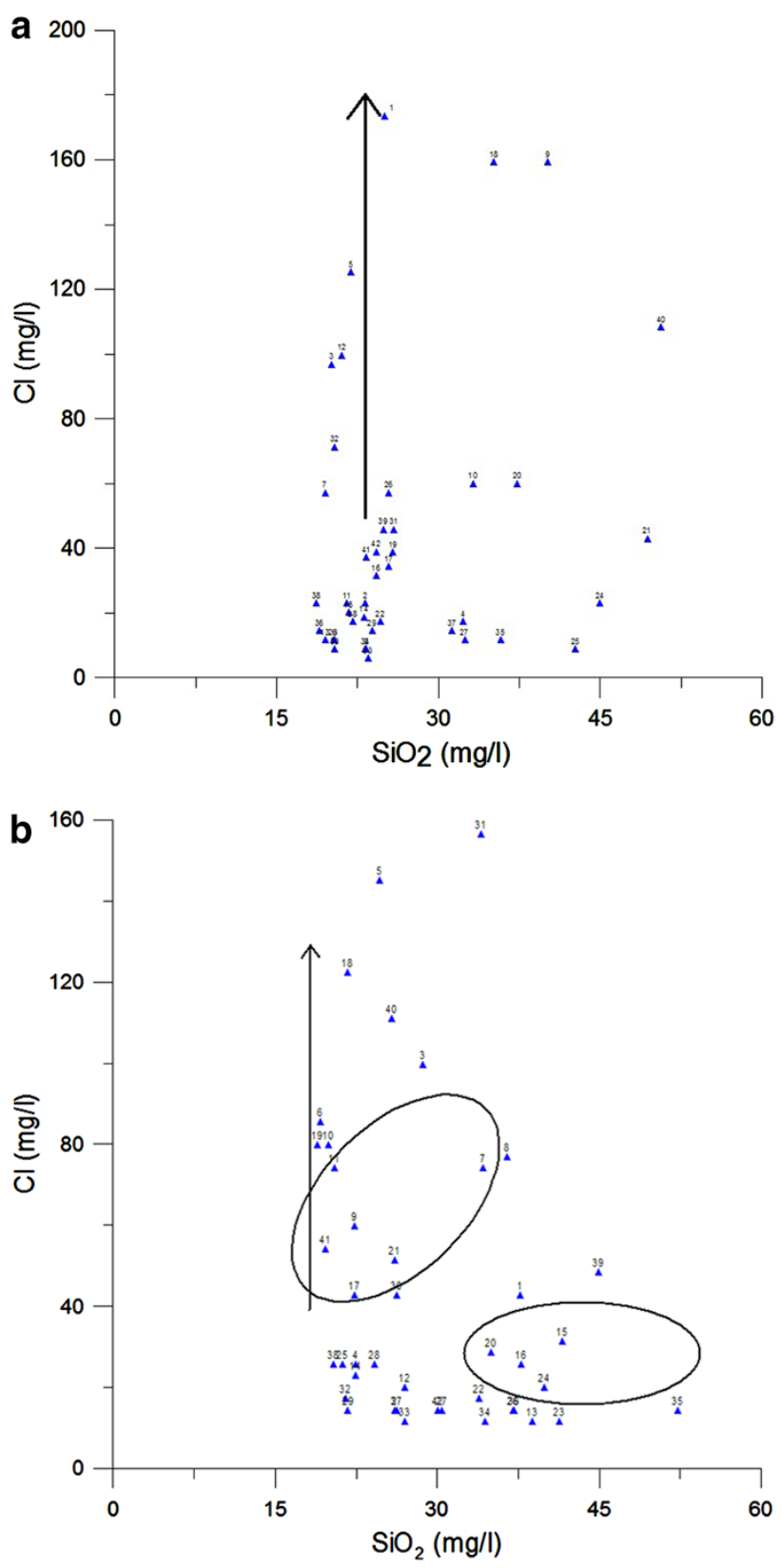

Fig. 3 a $\mathrm{SiO}_{2}$ vs. $\mathrm{Cl}$ plot (May 2012). b $\mathrm{SiO}_{2}$ vs. $\mathrm{Cl}$ plot (November 2012)

- Few samples $(6,10,11,18,19$ and 41) in the postmonsoon season show a trend similar to that of premonsoon with $\mathrm{Cl}$ values progressively increasing for almost constant $\mathrm{SiO}_{2}$ values of about 20-24 mg/l. This group shows relatively high $\mathrm{Cl}$ concentrations and average chalcedony temperature of about $31{ }^{\circ} \mathrm{C}$.

- A particular group of 7 samples $(7,8,9,17,21,30,41)$ shows a positive correlation with increasing $\mathrm{Cl}$ and $\mathrm{SiO}_{2}$ values and average chalcedony temperature of about $42{ }^{\circ} \mathrm{C}$ implying some contribution of water-rock interaction in acquisition of species. 
- Eight samples $(13,15,16,23,24,26,35,36)$ cluster to from a group with low $\mathrm{Cl}(11-31 \mathrm{mg} / \mathrm{l})$ and high $\mathrm{SiO}_{2}$ values (37-52 $\mathrm{mg} / \mathrm{l})$ and average chalcedony temperature of about $62{ }^{\circ} \mathrm{C}$ which corresponds to a depth of roughly $1,000 \mathrm{~m}$. At such depth water strongly interacts with rocks for relatively longer period and acquires silica in high proportions. Thus, these samples indicate geogenic processes contributing to ion acquisition.

\section{Relationship of silica with TDS}

$\mathrm{SiO}_{2}$ vs. TDS plot of both the seasons shows almost similar trend with most of the samples showing a very high TDS
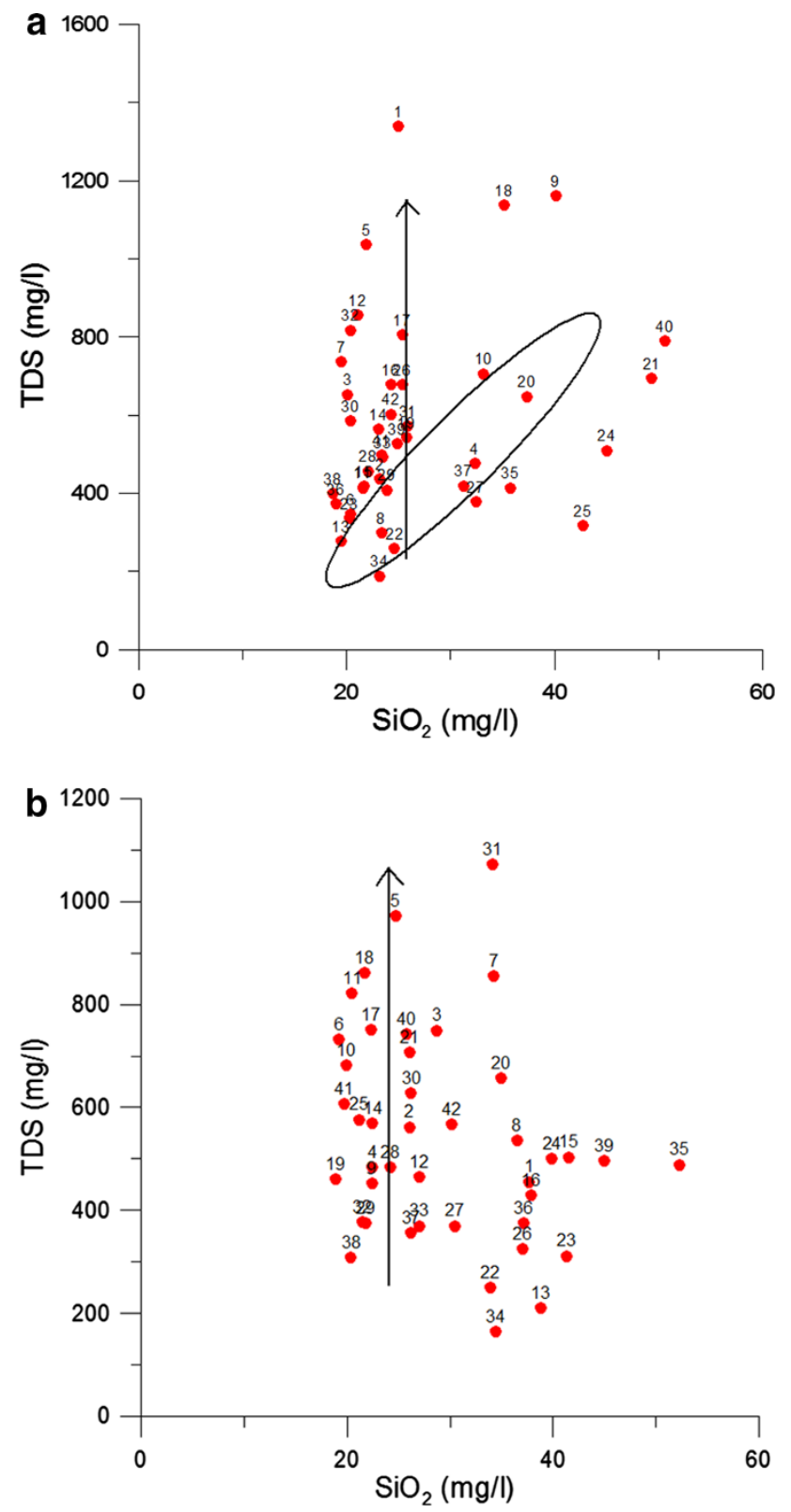

Fig. 4 a $\mathrm{SiO}_{2}$ vs. TDS plot (May 2012). b $\mathrm{SiO}_{2}$ vs. TDS plot (November 2012) value for a narrow range of silica values. Few significant points that can be deciphered from the pre-monsoon plot are:

- In Fig. 4a, for silica values between 19 and around $25 \mathrm{mg} / \mathrm{l}$ in the pre-monsoon season, TDS varies from approximately $188-1,037 \mathrm{mg} / \mathrm{l}$ suggesting that the bulk of TDS has been acquired by processes other than those responsible for acquisition of $\mathrm{SiO}_{2}$.

- Further, samples 4, 8, 10, 20, 22, 27, 34, 35 and 37 constituting a group shown on the plot exhibit a positive correlation between $\mathrm{SiO}_{2}$ and TDS, which indicates that both water-rock interaction and anthropogenic influences contribute to the chemistry of the groundwater.

The post-monsoon plot (Fig. 4b) clearly indicates increasing TDS values with near similar silica values. Most of the samples have silica values in the range of 19-28 mg/l with varying TDS reaching up to about $1,000 \mathrm{mg} / \mathrm{l}$. This suggests direct impact of anthropogenic activities on groundwater.

\section{Conclusion}

Silica geothermometry as applied to the present study shows that the groundwater of five different locations during each sampling season indicates high chalcedony temperature $>60{ }^{\circ} \mathrm{C}$, which correspond to a depth of more than 1,000 metres. Spatial variation of silica shows high values along a considerable stretch of River Kali, during pre-monsoon season, which suggests that river Kali is receiving groundwater discharge from local groundwater system and possibly from deeper and regional groundwater system, too. However, this trend is not observed during post-monsoon. This may be due to the enhanced circulation of groundwater in the shallow, local groundwater system, relatively deficient in silica. Relationship of silica with TDS and $\mathrm{Cl}^{-}$to infer the role of geogenic and anthropogenic processes in solute acquisition showed that both water-rock interaction and anthropogenic influences are responsible for the observed water chemistry.

Acknowledgments The financial assistance received by first author in the form of Junior Research Fellowship from University Grant Commission, New Delhi is acknowledged. The authors are thankful to the reviewers for their suggestions that improved the work. Thanks are due to Chairman, Department of Geology, Aligarh Muslim University, Aligarh for providing the basic facilities to carry out the work.

Open Access This article is distributed under the terms of the Creative Commons Attribution License which permits any use, distribution, and reproduction in any medium, provided the original author(s) and the source are credited.

\section{References}

APHA (1992) Standard methods for the examination of water and waste waters, 18th edn. American Public Health Association, Washington DC

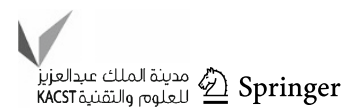


Arnorsson S (2000) Isotopic and chemical techniques in geothermal exploration, development and use. Sampling methods, data handling, interpretation. International Atomic Energy Agency, Vienna, p 351

Barbara AD, Harry IN (1984) Relationships between ground-water silica, total dissolved solids, and specific electrical conductivity. Groundwater 22(1):80-85

Boughton CJ, McCoy JK (2006) Hydrogeology, aquifer geochemistry and groundwater quality in Morgan County. Scientific invetsigation report 2006. US department of interior and US Geological Survey, Reston

CGWB (2002) Groundwater resource and development potentials of Aligarh, Uttar Pradesh. Central Ground Water Board, Ministry of Water Resources, pp 40

El-Fiky AA (2009) Hydrogeochemistry and geothermometry of thermal groundwater from the Gulf of Suez region, Egypt. Earth Sci 20(2):71-96

Ellis AJ (1970) Quantitative interpretation of chemical characteristics of hydrothermal systems. Geothermics 2:516-527

Ferguson G, Grasby SE, Hindle SR (2009) What do aqueous geothermometers really tell us? Geofluids 9:39-48

Fournier RO (1983) A revised and expanded silica geothermometer. Bull Geotherm Resour Counc 11:329

Fridriksson T, Armannsson H (2007) Application of geochemistry in geothermal resource assessments. In: Short course on geothermal development in Central America resource assessment and environmental management, El-Salvador, 25 Nov-1 Dec 2007

Geological Survey of India (1991) Geothermal atlas of India, special publication no. 19

Hailemichael DW (2008) Origin of geothermal waters and subsurface temperature estimates in the southern lowlands of Iceland. Geothermal training programme, reports 2008 , no. 28
Hem JD (1959) Study and interpretations of chemical characteristics of natural water. USGS 2254:263 Water Supply Paper

Karingthi CW (2009) Chemical geothermometers for geothermal exploration. Short course IV on exploration for geothermal resources, Kenya, 1-22 Nov 2009

Khan MMA, Umar R (2010) Significance of silica analysis in groundwater in parts of Central Ganga plain, Uttar Pradesh, India. Current Sci 98(9):1237-1240

Marchand D, Rayan MC, Bethune DN, Chu A (2002) Groundwatersurface water interaction and nitrate origin in municipal water supply aquifers, Sanjose, Costa Rica

McMahon PB, Vroblesky DA, Bradley PM, Chapelle FH, Gullett CD (1995) Evidence for enhanced mineral dissolution in organic acid-rich shallow groundwater. Groundw J 33(2):207-216

Morey GW, Fournier RO, Rowe JJ (1962) The solubility of quartz in water in the temperature interval from 29 to $300^{\circ} \mathrm{C}$. Geochim Cosmochim Acta 26:1029-1043

Swanberg CA, Morgan P (1978) The linear relation between temperatures based on the silica content of groundwater and regional heat flow: a new heat flow map of the united state. J Pure Appl Geophys 117(1-12):227-241

Truesdell AH, Fournier RO (1977) Procedure for estimating the temperature of a hot water component in mixed water by using a plot of dissolved silica versus enthalpy. USGS J Res 5:49-52

Verma MP (2000) Limitations in applying silica geothermometers for geothermal reservoir evaluation. In: Proceedings, 25th workshop on geothermal reservoir engineering, Stanford University, Stanford, 24-26 Jan 2000 